\title{
Prokaryotic Communities in the Thalassohaline Tuz Lake, Deep Zone, and Kayacik, Kaldirim and Yavsan Salterns (Turkey) Assessed by 16S rRNA Amplicon Sequencing
}

\author{
Can Akpolat ${ }^{1}\left(\mathbb{D}\right.$, Ana Beatriz Fernández ${ }^{2} \mathbb{D}$, Pinar Caglayan ${ }^{1} \mathbb{D}$, Baris Calli ${ }^{3} \mathbb{D}$, Meral Birbir $^{1, *}(\mathbb{D})$ \\ and Antonio Ventosa $4, *$ (iD \\ 1 Department of Biology, Faculty of Arts and Sciences, Marmara University, 34722 Istanbul, Turkey; \\ canakpolat@marun.edu.tr (C.A.); pinar.caglayan@marmara.edu.tr (P.C.) \\ 2 Institute for Multidisciplinary Research in Applied Biology-IMAB, Universidad Publica de Navarra, Multilva, \\ 31006 Navarra, Spain; anabeatriz.fernandez@unavarra.es \\ 3 Department of Environmental Engineering, Faculty of Engineering, Marmara University, \\ 34722 Istanbul, Turkey; baris.calli@marmara.edu.tr \\ 4 Department of Microbiology and Parasitology, Faculty of Pharmacy, University of Sevilla, 41004 Sevilla, Spain \\ * Correspondence: mbirbir@marmara.edu.tr (M.B.); ventosa@us.es (A.V.); Tel.: +90-216-777-3200 (M.B.); \\ +34-954-556-765 (A.V.)
}

check for

updates

Citation: Akpolat, C.; Fernández, A.B.; Caglayan, P.; Calli, B.; Birbir, M.; Ventosa, A. Prokaryotic Communities in the Thalassohaline Tuz Lake, Deep Zone, and Kayacik, Kaldirim and Yavsan Salterns (Turkey) Assessed by 16S rRNA Amplicon Sequencing. Microorganisms 2021, 9, 1525. https:// doi.org/10.3390/microorganisms 9071525

Academic Editor: Ricardo Amils

Received: 20 June 2021

Accepted: 13 July 2021

Published: 17 July 2021

Publisher's Note: MDPI stays neutral with regard to jurisdictional claims in published maps and institutional affiliations.

Copyright: (c) 2021 by the authors. Licensee MDPI, Basel, Switzerland. This article is an open access article distributed under the terms and conditions of the Creative Commons Attribution (CC BY) license (https:// creativecommons.org/licenses/by/ $4.0 /)$.

\begin{abstract}
Prokaryotic communities and physico-chemical characteristics of 30 brine samples from the thalassohaline Tuz Lake (Salt Lake), Deep Zone, Kayacik, Kaldirim, and Yavsan salterns (Turkey) were analyzed using 16S rRNA amplicon sequencing and standard methods, respectively. Archaea (98.41\% of reads) was found to dominate in these habitats in contrast to the domain Bacteria (1.38\% of reads). Representatives of the phylum Euryarchaeota were detected as the most predominant, while 59.48\% and $1.32 \%$ of reads, respectively, were assigned to 18 archaeal genera, 19 bacterial genera, 10 archaeal genera, and one bacterial genus that were determined to be present, with more than $1 \%$ sequences in the samples. They were the archaeal genera Haloquadratum, Haloarcula, Halorhabdus, Natronomonas, Halosimplex, Halomicrobium, Halorubrum, Halonotius, Halolamina, Halobacterium, and Salinibacter within the domain Bacteria. The genera Haloquadratum and Halorhabdus were found in all sampling sites. While Haloquadratum, Haloarcula, and Halorhabdus were the most abundant genera, two uncultured Tuz Lake Halobacteria (TLHs) 1 and 2 were detected in high abundance, and an additional uncultured haloarchaeal TLH-3 was found as a minor abundant uncultured taxon. Their future isolation in pure culture would permit us to expand our knowledge on hypersaline thalassohaline habitats, as well as their ecological role and biomedical and biotechnological potential applications.
\end{abstract}

Keywords: Tuz Lake (Salt Lake); thalassohaline lakes; salterns; metagenomics; extremophiles; $16 \mathrm{~S}$ rRNA amplicon sequencing; physico-chemical analyses

\section{Introduction}

Hypersaline habitats such as salt lakes, saline soils, solar salterns, hypersaline soda lakes, salt mines, and deep-sea and oil reservoir brines are typical extreme environments in which not only $\mathrm{NaCl}$, but other environmental factors, such as $\mathrm{pH}$, temperature, nutrients, radiation, pressure or presence of heavy metals and other toxic compounds, limit their microbiota [1-8].

Hypersaline aquatic environments are classified as thalassohaline habitats; those derived from marine origin having relative proportions of salts according to those of seawater, and athalassohaline aquatic systems, with salts proportions very different from seawater, reflecting their non-marine and very different geological origins [1,2,4]. Most studies on hypersaline lakes have been focused on athalassohaline lakes, such as the Dead Sea, hypersaline and alkaline (soda) lakes in Antarctica, East African lakes such as Lake Magadi and the lakes of Wadi Natrun, in Australia or China, especially in Inner 
Mongolia region, and deep-sea lakes [1,2,8-14]. These environments, which host a wide variety of microorganisms belonging to Archaea and Bacteria, have attracted considerable attention in recent years in terms of the microbial diversity and their adaptations to high salt concentrations, as well as on the biotechnological and industrial applications of these extremophilic microorganisms [5,15-17]. However, relatively little is known about the prokaryotic diversity in thalassohaline lakes, including the hypersaline Tuz Lake and its associated salterns, in Turkey.

The hypersaline Tuz Lake (in Turkish Tuz Gölü), located in the Konya Closed Basin on the Central Anatolian Peninsula, is the largest hypersaline lake in Turkey, with a maximum surface area of $1665 \mathrm{~km}^{2}$ [18]. It has an average altitude of $905 \mathrm{~m}$ and is surrounded by the Kizilırmak massif in the east, Obruk Plateau in the south, Cihanbeyli Plateau in the west, and the Haymana Plateau in the north [19]. Tuz Lake constitutes the Main Zone (a water body with a depth of about $70 \mathrm{~cm}$ in the spring) and a separate area of the lake, designated as the Deep Zone (a water body with a depth exceeding $100 \mathrm{~cm}$ in the spring), is found in the mid-east part of the main area of the lake [20,21]. In addition, on the shore of Tuz Lake, there are several salterns that are the major source for salt production in Turkey, estimated to meet $70 \%$ of the salt needs of this country [22,23]. Kayacik saltern, Kaldirim saltern, and Yavsan saltern are located in the mid-east, north-east, and western parts of the lake, respectively (Figure 1). The lake is a closed water basin where the water partly filters into the soil and partly evaporates. The lake is mostly fed by underground water and partially by the small rivers that come from Konya Closed Basin and Obruk Plateau. In summer, most of the incoming streams dry up and do not reach the lake. Due to the excessive evaporation, the lake dries out almost completely and about $30 \mathrm{~cm}$ thick salt layers are formed. The average salt content and density of the lake water are $32.4 \%$ and $2-2.5 \mathrm{~g} / \mathrm{cm}^{3}$, respectively [24]. The annual average temperature is $12{ }^{\circ} \mathrm{C}\left(1.6{ }^{\circ} \mathrm{C}\right.$ in winter and $22.2{ }^{\circ} \mathrm{C}$ in summer, respectively), and the mean annual precipitation is $324 \mathrm{~mm} / \mathrm{m}^{2}$. Tuz Lake and the surrounding area have been determined as the most arid regions in Turkey.

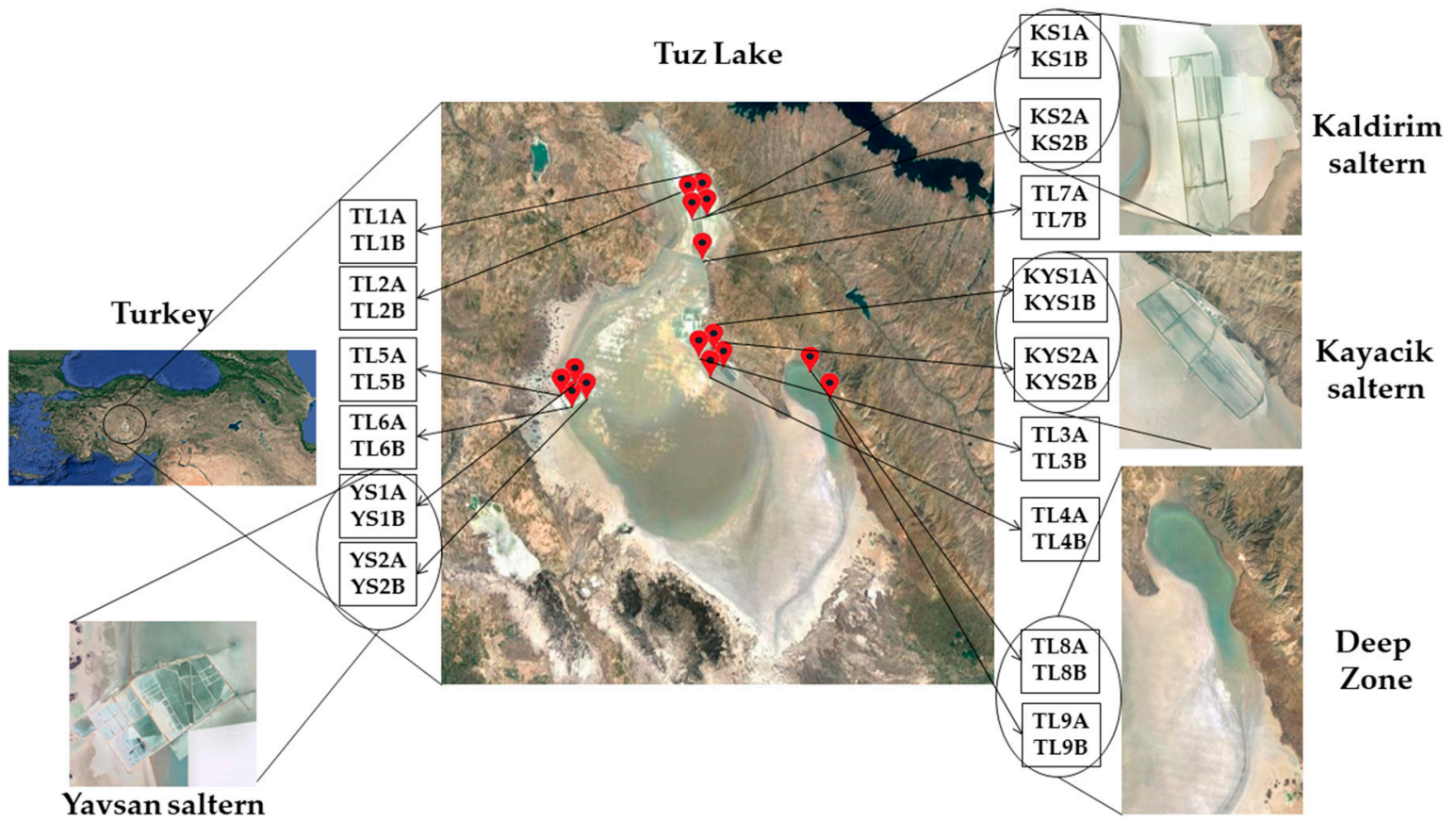

Figure 1. Locations of the sampling sites and 30 brine samples collected from Tuz Lake, Deep Zone, and Kayacik, Kaldirim, and Yavsan salterns in Turkey.

Some pollution load reaches the Tuz Lake from various sources located around the lake, especially sulfate-rich wastewater from a sodium sulfate manufacturing plant in the southwest, and partially treated domestic wastewater discharged into the small creeks 
feeding the lake, and to a lesser extent the metal residue particles of the mining activities and fertilizer and pesticide residues originating from the agricultural activities in the region [19].

The prokaryotic diversity of Tuz Lake has been mostly investigated using culturedependent methods, permitting the isolation of moderately halophilic bacterial and extremely halophilic archaeal strains that produced lipases and proteases, and to a lower extent cellulase and $\beta$-galactosidase enzymes [22,25-28]. More recently, the archaeal and bacterial diversity of the lake, using culture-independent methods, has been investigated [18,29-32]. A higher percentage of the archaeal community than that of the bacterial community was detected by FISH. Based on the 16S rRNA gene library data, Haloquadratum and Salinibacter ruber related phylotypes were found as the predominant microorganisms [29]. In another culture-independent study carried out in Tuz Lake, in the five brine samples studied, 29 archaeal and 23 bacterial OTUs were detected using 16S rDNA metabarcoding. The OTUs of Haloquadratum walsbyi and the genus Salinibacter were found as the most predominant in these samples [30]. Moreover, the bacterial composition of Tuz Lake was examined by the V3-V4 variable regions of bacterial 16S rRNA gene. Firmicutes, Fusobacteria, and Proteobacteria were determined as the most abundant bacterial phyla in two brine samples of the lake [31].

In a recent study, the bacterial and archaeal diversity found in 11 sediment samples collected from Cihanbeyli and Şereflikoçhisar regions of Tuz Lake were examined by the comparison of the V4 region of 16S rRNA gene, using Illumina MiSeq sequencing platform and cloning. While Gammaproteobacteria, Bipolaricaulia, Desulfovibrionia, candidate division MSBL-1, Bacteroidia, and Desulfobacteria were detected as the most abundant classes, Gemmatimonadota_c, Rhodothermia, Alphaproteobacteria, Methanonatronarchaeia, Thermoplasmata, Halanaerobiia, Desulfobulbia, and Bacilli were found as low abundance classes [18].

Overall, previous microbiological studies using culture-independent analyses were limited to a small number of samples and sampling areas compared to the great extent of the lake or were restricted to the study of bacteria or sediments of Tuz Lake [18,29-31]. In this study, we have determined the composition and abundance of prokaryotic communities present in the brines of different sampling sites of Tuz Lake, including the Deep Zone, as well as the three salterns, Kayacik, Kaldirim, and Yavsan that are associated with the lake, through 16S rRNA gene amplicon sequencing.

\section{Materials and Methods}

\subsection{Brine Sample Collection}

Thirty brine samples were collected in July 2017 from 15 different sampling sites ( 2 brine samples per site), as shown in Figure 1. The Deep Zone, with a depth of about $1 \mathrm{~m}$, is located at the east of Tuz Lake and was previously part of the lake. However, drought has caused a permanent separation of this area from Tuz Lake. Kayacik, Kaldirim, and Yavsan salterns are located on the shores of the Tuz Lake.

The samples were coded according to the sampling sites: Tuz Lake (TL1A-TL1B, TL2A-TL2B, TL3A-TL3B, TL4A-TL4B, TL5A-TL5B, TL6A-TL6B, TL7A-TL7B), Deep Zone (TL8A-TL8B, TL9A-TL9B), Kayacik saltern (KYS1A-KYS1B, KYS2A-KYS2B), Kaldirim saltern (KS1A-KS1B, KS2A-KS2B), and Yavsan saltern (YS1A-YS1B, YS2A-YS2B). The brine samples were collected in sterile bottles, carried to the laboratory on ice in the dark, and processed immediately (Figure 1).

\subsection{Physico-Chemical Analyses}

In-situ measurements of temperature and $\mathrm{pH}$ of the brine samples were performed using a portable pH meter (PT 10, Sartorius Professional Meter PP-50 AG, Göttingen, Germany). The salinity of the brine samples was measured using a hand refractometer (Reef Octopus, China). Chloride concentrations of the brines were determined by argentometric method [33,34]. Sodium, potassium, magnesium, and calcium concentrations in the brine samples were determined using a flame atomic absorption spectroscopy (FAAS) (Perkin 
Elmer, AAS 400, Waltham, MA, USA) via air-acetylene flame [35]. Linear ranges used in the analyses were $10-100 \mathrm{mg} \mathrm{L}^{-1}$ for $\mathrm{Na}^{+}, 1-20 \mathrm{mg} \mathrm{L}^{-1}$ for $\mathrm{K}^{+}, 0.1-2 \mathrm{mg} \mathrm{L}^{-1}$ for $\mathrm{Mg}^{2+}$, and 20-100 $\mathrm{mg} \mathrm{L}^{-1}$ for $\mathrm{Ca}^{2+}$.

\subsection{DNA Extraction from the Brine Samples}

A total of $1.5 \mathrm{~L}$ of the brine sample was sequentially filtered through $5 \mu \mathrm{m}$ and $0.2 \mu \mathrm{m}$ pore size filters, using a peristaltic pump [36-38]. Cells obtained from the filters were resuspended in $2.5 \mathrm{M} \mathrm{NaCl}$, then separately placed into sterile tubes and centrifuged at 13,000 rpm for $30 \mathrm{~min}$. The environmental DNA was extracted from each sample using the PowerSoil DNA isolation kit (Qiagen, USA), according to the manufacturer's protocol [38]. The quantity and quality of the extracted DNA were analyzed by a Nanodrop spectrophotometer (NanoDrop 2000) at 260/280 nm and 260/230 nm, and by agarose gel electrophoresis. The extracted DNA samples were stored at $-20{ }^{\circ} \mathrm{C}$ until further processing [39].

\subsection{S rRNA Amplicon Processing from the Extracted DNA Samples}

The V6-V8 variable regions of archaeal and bacterial 16S rRNA genes of the extracted DNA belonging to the brine samples were amplified using forward primer $926 \mathrm{~F}\left(5^{\prime}\right.$ AAACTYAAAKGAATTGRCGG-3') and reverse primer 1392R (5'-ACGGGCGGTGTGTRC$3^{\prime}$ ) [40]. PCR amplification was performed using the HotStarTaq Plus Master Mix (Qiagen, USA). The following PCR conditions were used: initial denaturation at $94^{\circ} \mathrm{C}$ for $3 \mathrm{~min}$, followed by 28 cycles at $94{ }^{\circ} \mathrm{C}$ for $30 \mathrm{~s}$, at $53{ }^{\circ} \mathrm{C}$ for $40 \mathrm{~s}$, and $72{ }^{\circ} \mathrm{C}$ for $60 \mathrm{~s}$, followed by final extension step at $72{ }^{\circ} \mathrm{C}$ for $5 \mathrm{~min}$. After the PCR amplification step, PCR products were run on $2 \%$ agarose gel. The concentration of each PCR product was measured and pooled equimolarly. The pooled amplicons were purified using AMPure XP (Beckman Coulter, Brea, CA, USA) magnetic beads. The pooled and purified amplicons were subjected to NGS library preparation protocol for Illumina. Sequencing was performed on the Illumina MiSeq platform with 300 bp paired-end chemistry (Macrogen Inc., Seoul, Korea).

\subsection{Bioinformatic Analysis}

The quality of the raw data was evaluated using the FastQC program [41]. 16S rRNA gene amplicon data were merged and analyzed with the QIIME program [42]. Demultiplexing was performed using barcode sequences specific to each sample. Then, the Illumina MiSeq reads were quality filtered by removing low-quality or ambiguous reads. All barcode and primer sequences were removed and the reads were clustered at $97 \%$ identity in operational taxonomic units (OTUs) using UCLUST [43]. A representative sequence for each OTU was selected and all representative OTU sequences were aligned with PyNAST v1.2.2 [44] using the Greengenes (GreenGenes v13.8) database. Chimeric fragments were detected with the ChimeraSlayer algorithm [45] and all chimeric reads were excluded. In addition, OTUs with only one read were discarded. Then, the OTU table was formed, including information of read counts of each OTU belonging to the sample. Taxonomic classification of the OTU table was performed using the UCLUST program and Greengenes database. Alpha diversity analyses were also performed with the QIIME program using the OTU table and diversity indexes (PD Whole Tree, Chao1, Observed OTUs, Shannon, Simpson, and Dominance) were calculated. Beta diversity analyses were performed using weighted and unweighted unifrac metrics and visualized as principal component analysis (PCA) graphs. Rarefaction curves were generated by QIIME pipeline v1.9.1 [42].

\subsection{Statistical Analyses}

In the present study, statistical correlations among the abundance of archaeal and bacterial genera were performed using the $\mathrm{R}$ software. The correlation among different variables was analyzed by the "cor" function using the R software. Principal component analysis was made by the "prcomp" function [46]. 


\subsection{Sequencing Data}

All sequence data obtained in this study are freely available at the European $\mathrm{Nu}$ cleotide Archive (ENA)/NCBI under the accession number PRJNA705280.

\section{Results}

\subsection{Physico-Chemical Analyses}

The 30 brine samples collected from Tuz Lake, Deep Zone, and Kayacik, Kaldirim, and Yavsan salterns were analyzed to determine the physico-chemical characteristics (Table S1). High salinity and near-neutral $\mathrm{pH}$ values were observed in all brine samples. Salinity of the samples from Tuz Lake and Deep Zone ranged from 30 to 38\%, with intermediate values of 32,34 , and $36 \%$ from several sampling sites. The salinity of the samples from Kayacik, Kaldirim, and Yavsan salterns was also very high, with percentages of 30-32, 32-36, and $32 \%$, respectively. The $\mathrm{pH}$ of the samples ranged between 6.9 (only two sampling sites) and 7.4 , and the temperature of the brine samples was very constant, ranging from 25 to $27^{\circ} \mathrm{C}$, except for some of Tuz Lake samples and all Deep Zone samples for which the temperature was 22 and $24{ }^{\circ} \mathrm{C}^{-\mathrm{Na}^{+}}$and $\mathrm{Cl}^{-}$contents were fairly high in all brine samples. Although $\mathrm{K}^{+}$and $\mathrm{Mg}^{2+}$ contents were found as moderate, low $\mathrm{Ca}^{2+}$ concentrations were determined for all samples studied (Table S1). Overall, these data, especially the neutral $\mathrm{pH}$ and high content of $\mathrm{Na}^{+}$and $\mathrm{Cl}^{-}$concentrations, in contrast to divalent cations, corroborate the thalassohaline character of Tuz Lake and the salterns investigated in this study.

\subsection{Alpha Diversity and Richness Metrics}

In the present study, a total of 1,282,558 16S rRNA gene sequences obtained from the 30 brine samples were clustered into 17,488 OTUs at $97 \%$ sequence similarity. YS2A sample, obtained from Yavsan saltern, had the maximal values according to both, the number of sequences $(97,361)$ and OTUs $(5725)$. In contrast, the Tuz Lake and Deep Zone samples TL4A and TL8B had minimal values in terms of the sequence count $(26,179)$ and OTU number (707), respectively.

Although samples from Tuz Lake and Deep Zone showed slopes on the rarefaction curves close to zero or gentle slope, samples from Kayacik, Kaldirim, and Yavsan salterns had raised slopes, suggesting that the deep sequencing was insufficient to cover the diversity in these few samples (Figure S1).

To examine the diversity and richness in Tuz Lake, Deep Zone, and Kayacik, Kaldirim, and Yavsan salterns, observed OTUs, PD whole tree, Chao1, Shannon, Simpson, and Dominance indexes were calculated. Chao1 and Shannon indexes indicated that the highest diversities were detected in TL2 and KS1 sampling regions and the lowest diversities were detected in TL8-TL9 sampling sites corresponding to the Deep Zone (Table 1). Brine samples of the Deep Zone had lower OTU numbers than those of brine samples of Tuz Lake and its salterns, and consequently, lower prokaryotic diversity was detected at this region because of a large dominance of a few OTUs (Table 1).

Table 1. Prokaryotic richness and diversity estimates, based on 97\% OTU clusters of Tuz Lake, Deep Zone, and Kayacik, Kaldirim, and Yavsan salterns. The diversity indexes: PD Whole Tree, Chao1, Shanon, Simpson, and Dominance were calculated.

\begin{tabular}{ccccccc}
\hline Sample & PD Whole Tree & Chao 1 & Observed OTUs & Shannon & Simpson & Dominance \\
\hline Tuz Lake & & & & & & \\
TL1A & 39.02 & 2879.40 & 1517.00 & 6.22 & 0.94 & 0.06 \\
TL1B & 41.00 & 3388.46 & 1753.00 & 6.09 & 0.94 & 0.06 \\
TL2A & 77.94 & 8354.98 & 3799.00 & 7.50 & 0.95 & 0.05 \\
TL2B & 88.63 & 9402.42 & 4539.00 & 6.82 & 0.96 & 0.04 \\
TL3A & 56.38 & 5378.22 & 2756.00 & 7.23 & 0.90 & 0.10 \\
TL3B & 60.63 & 5983.23 & 2881.00 & 6.75 & 0.95 & 0.05 \\
TL4A & 53.08 & 3761.75 & 1936.00 & & 0.05 \\
\hline
\end{tabular}


Table 1. Cont.

\begin{tabular}{|c|c|c|c|c|c|c|}
\hline Sample & PD Whole Tree & Chao 1 & Observed OTUs & Shannon & Simpson & Dominance \\
\hline TL4B & 59.47 & 3958.28 & 2357.00 & 7.23 & 0.96 & 0.04 \\
\hline TL5A & 64.97 & 6757.91 & 3134.00 & 8.11 & 0.98 & 0.02 \\
\hline TL5B & 76.81 & 7325.52 & 3930.00 & 8.46 & 0.98 & 0.02 \\
\hline TL6A & 57.09 & 5566.74 & 2674.00 & 5.38 & 0.77 & 0.23 \\
\hline TL6B & 69.76 & 7010.20 & 3450.00 & 6.15 & 0.84 & 0.16 \\
\hline TL7A & 51.98 & 4779.82 & 2134.00 & 5.73 & 0.89 & 0.11 \\
\hline TL7B & 53.02 & 4555.30 & 2241.00 & 5.24 & 0.80 & 0.20 \\
\hline \multicolumn{7}{|c|}{ Deep Zone } \\
\hline TL8A & 24.94 & 1805.01 & 914.00 & 4.43 & 0.82 & 0.18 \\
\hline TL8B & 20.61 & 1480.57 & 707.00 & 4.29 & 0.79 & 0.21 \\
\hline TL9A & 23.76 & 1684.02 & 883.00 & 4.65 & 0.85 & 0.15 \\
\hline TL9B & 26.09 & 2007.02 & 1008.00 & 4.55 & 0.83 & 0.17 \\
\hline \multicolumn{7}{|c|}{ Kayacik saltern } \\
\hline KYS1A & 71.63 & 8049.00 & 3488.00 & 6.98 & 0.91 & 0.09 \\
\hline KYS1B & 58.10 & 6263.30 & 2768.00 & 6.94 & 0.91 & 0.09 \\
\hline KYS2A & 40.67 & 3763.57 & 1812.00 & 5.52 & 0.90 & 0.10 \\
\hline KYS2B & 34.26 & 2669.73 & 1453.00 & 5.31 & 0.90 & 0.10 \\
\hline \multicolumn{7}{|c|}{ Kaldirim saltern } \\
\hline KS1A & 78.75 & 8057.13 & 4026.00 & 8.27 & 0.98 & 0.02 \\
\hline KS1B & 81.74 & 8825.45 & 4242.00 & 8.19 & 0.97 & 0.03 \\
\hline KS2A & 78.01 & 8276.09 & 3692.00 & 7.24 & 0.94 & 0.06 \\
\hline $\mathrm{KS} 2 \mathrm{~B}$ & 67.12 & 6241.22 & 2900.00 & 6.66 & 0.91 & 0.09 \\
\hline \multicolumn{7}{|c|}{ Yavsan saltern } \\
\hline YS1A & 32.29 & 2572.08 & 1321.00 & 5.16 & 0.82 & 0.18 \\
\hline YS1B & 70.16 & 6340.94 & 3174.00 & 5.98 & 0.85 & 0.15 \\
\hline YS2A & 104.00 & $10,259.51$ & 5725.00 & 7.17 & 0.92 & 0.08 \\
\hline YS2B & 85.79 & 8352.18 & 4468.00 & 7.28 & 0.92 & 0.08 \\
\hline
\end{tabular}

3.3. Prokaryotic Communities in Tuz Lake, Deep Zone, and Kayacik, Kaldirim, and Yavsan Salterns

Our analyses indicated that most $16 \mathrm{~S}$ rRNA gene sequences were classified within the domain Archaea (98.41\%) and clustered into 16,939 OTUs. In contrast, only a few sequences could be assigned to the domain Bacteria $(1.38 \%)$ and they clustered into 218 OTUs. Fifty-one OTUs belonging to the archaeal class Halobacteria and one OTU belonging to the bacterial class Rhodothermia, family Salinibacteraceae were determined in all the brine samples collected from Tuz Lake, Deep Zone, and Kayacik, Kaldirim, and Yavsan salterns.

The archaeal phylum Euryarchaeota (93.76-99.94\%, with a mean of $98.41 \pm 0.27 \%)$, and the bacterial phyla Rhodothermaeota $(0.02-5.52 \%, 1.28 \pm 0.25 \%)$, Proteobacteria $(0.00-0.83 \%$, $0.06 \pm 0.03 \%)$, Firmicutes $(0.00-0.33 \%, 0.02 \pm 0.01 \%)$, and Lentisphaerae $(0.00-0.11 \%, 0.009 \pm 0.005 \%)$ were found in the samples. In addition, the archaeal phylum Parvarchaeota $(0.00-0.003 \%)$ and the bacterial phyla Actinobacteria $(0.00-0.008 \%, 0.001 \pm 0.0003 \%)$, Spirochaetes $(0.00-0.004 \%)$ and Cyanobacteria $(0.00-0.01 \%, 0.001 \pm 0.0005 \%)$ were detected at extremely low abundance in a few brine samples. According to these data, Euryarchaeota, distantly followed by Rhodothermaeota, were the most abundant phyla determined in all brine samples studied (Figure 2).

The phyla composition detected in all brine samples of Tuz Lake, and Kayacik, Kaldirim and Yavsan salterns were fairly similar, except for the Deep Zone (Table S2). It is noteworthy that the two brine replicates collected per site shared a quite similar phyla composition (Figure 2). The highest percentage of Euryarchaeota was detected at the brine samples of the Deep Zone. Rhodothermaeota was found slightly more abundant in some locations of Tuz Lake (TL2, TL3, TL4, TL6, and TL7 sampling sites), Kayacik saltern (KYS1 samples), Kaldirim saltern (KS1 and KS2 samples), and Yavsan saltern (YS1 and YS2 samples) (Figure 2). 


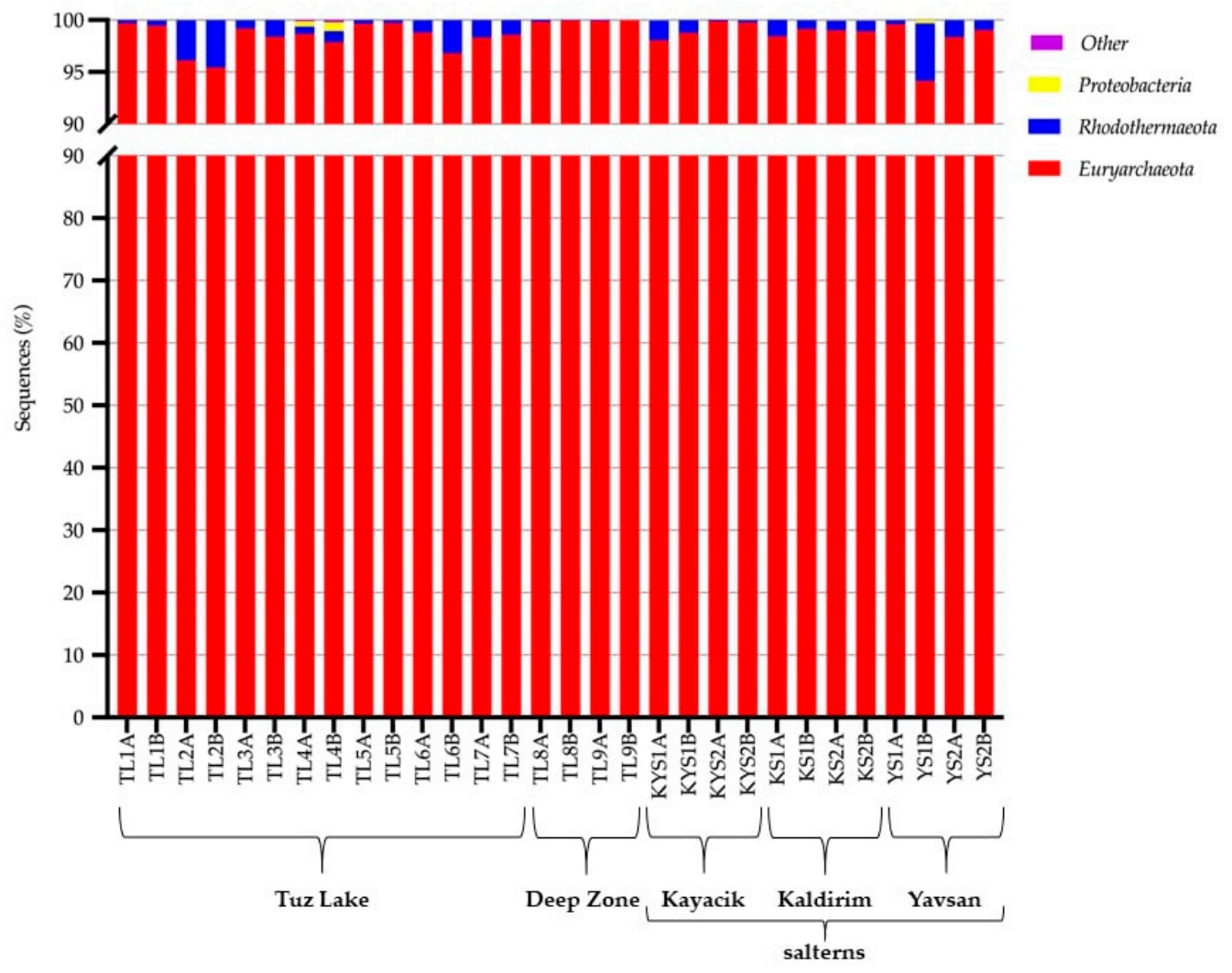

Figure 2. Phyla distributions of prokaryotic communities determined in brine samples of Tuz Lake (TL1A to TL7B), Deep Zone (TL8A to TL9B), and Kayacik (KYS1A to KYS2B), Kaldirim (KS1A to KS2B), and Yavsan (YS1A to YS2B) salterns.

At genus level, most of the sequences were classified in the phylum Euryarchaeota, being the OTU classified in the genus Haloquadratum remarkably abundant in most of the samples (Figure 3). However, a large number of sequences clustered into OTUs that could not be assigned to any known genera (39\% of sequences). Thus, only $61 \%$ of sequences obtained in this study were assigned or closely related to previously described genera. Two uncultured OTUs were well represented in these samples and both belonged or were related to the class Halobacteria. Besides, the genera Haloarcula and Halorhabdus also recruited many sequences in these environments. In contrast, only $1.38 \%$ of sequences were assigned to Bacteria and most of them were related to the genus Salinibacter (Table 2 and Figure 3).

Table 2. Taxonomic distribution at the genus level, with more than $0.3 \%$ sequences detected in the brine samples collected from Tuz Lake, Deep Zone, and Kayacik, Kaldirim, and Yavsan salterns.

\begin{tabular}{|c|c|c|c|c|c|c|}
\hline Genus/Taxon & Phylum & Tuz Lake & Deep Zone & Kayacik Saltern & Kaldirim Saltern & Yavsan Saltern \\
\hline $\begin{array}{c}\text { Uncultured } \\
\text { Halobacteria TLH-1 }\end{array}$ & Euryarchaeota & $24.61 \pm 3.20$ & $5.43 \pm 0.28$ & $10.65 \pm 2.66$ & $31.77 \pm 4.86$ & $17.93 \pm 2.12$ \\
\hline $\begin{array}{l}\text { Haloquadratum } \\
\text { Haloarcula }\end{array}$ & $\begin{array}{l}\text { Euryarchaeota } \\
\text { Euryarchaeota }\end{array}$ & $\begin{array}{l}23.99 \pm 4.25 \\
14.36 \pm 4.32\end{array}$ & $\begin{array}{c}47.32 \pm 1.74 \\
0.03 \pm 0.00\end{array}$ & $\begin{array}{l}31.33 \pm 2.78 \\
1.80 \pm 0.79\end{array}$ & $\begin{array}{l}16.57 \pm 3.18 \\
14.52 \pm 6.39\end{array}$ & $\begin{array}{l}41.30 \pm 3.60 \\
5.46 \pm 1.42\end{array}$ \\
\hline $\begin{array}{l}\text { Uncultured } \\
\text { Halobacteria TLH-2 }\end{array}$ & Euryarchaeota & $13.98 \pm 1.04$ & $22.99 \pm 1.78$ & $36.18 \pm 5.85$ & $14.14 \pm 1.51$ & $16.40 \pm 2.16$ \\
\hline $\begin{array}{l}\text { Halorhabdus } \\
\text { Halorubrum }\end{array}$ & $\begin{array}{l}\text { Euryarchaeota } \\
\text { Euryarchaeota }\end{array}$ & $\begin{array}{l}6.90 \pm 0.93 \\
3.87 \pm 1.34\end{array}$ & $\begin{array}{c}23.76 \pm 1.95 \\
0.15 \pm 0.02\end{array}$ & $\begin{array}{c}14.22 \pm 2.93 \\
1.80 \pm 0.42\end{array}$ & $\begin{array}{l}6.40 \pm 0.69 \\
2.07 \pm 0.46\end{array}$ & $\begin{array}{l}8.82 \pm 1.78 \\
2.26 \pm 0.60\end{array}$ \\
\hline Halonotius & Euryarchaeota & $3.25 \pm 0.66$ & $0.02 \pm 0.00$ & $0.96 \pm 0.41$ & $4.69 \pm 1.65$ & $1.50 \pm 0.51$ \\
\hline Natronomonas & Euryarchaeota & $3.00 \pm 1.55$ & $0.02 \pm 0.00$ & $0.30 \pm 0.15$ & $2.99 \pm 1.39$ & $0.81 \pm 0.24$ \\
\hline Halolamina & Euryarchaeota & $1.73 \pm 0.91$ & $<0.01$ & $0.27 \pm 0.23$ & $2.15 \pm 0.17$ & $0.39 \pm 0.24$ \\
\hline Salinibacter & Rhodothermaeota & $1.54 \pm 0.37$ & $0.09 \pm 0.03$ & $0.88 \pm 0.42$ & $1.09 \pm 0.16$ & $2.10 \pm 1.13$ \\
\hline Halobacterium & Euryarchaeota & $1.19 \pm 0.53$ & $0.01 \pm 0.00$ & $0.04 \pm 0.02$ & $0.44 \pm 0.19$ & $0.51 \pm 0.27$ \\
\hline Halosimplex & Euryarchaeota & $0.58 \pm 0.11$ & $0.08 \pm 0.01$ & $0.37 \pm 0.14$ & $1.34 \pm 0.43$ & $0.67 \pm 0.23$ \\
\hline Halomicrobium & Euryarchaeota & $0.23 \pm 0.05$ & $0.01 \pm 0.00$ & $0.17 \pm 0.05$ & $0.84 \pm 0.36$ & $0.30 \pm 0.14$ \\
\hline Haloplanus & Euryarchaeota & $0.16 \pm 0.04$ & $0.01 \pm 0.00$ & $0.46 \pm 0.11$ & $0.42 \pm 0.09$ & $0.60 \pm 0.11$ \\
\hline $\begin{array}{l}\text { Uncultured } \\
\text { Halobacteria TLH-3 }\end{array}$ & Euryarchaeota & $0.07 \pm 0.02$ & $0.00 \pm 0.00$ & $0.06 \pm 0.03$ & $0.22 \pm 0.05$ & $0.34 \pm 0.14$ \\
\hline
\end{tabular}




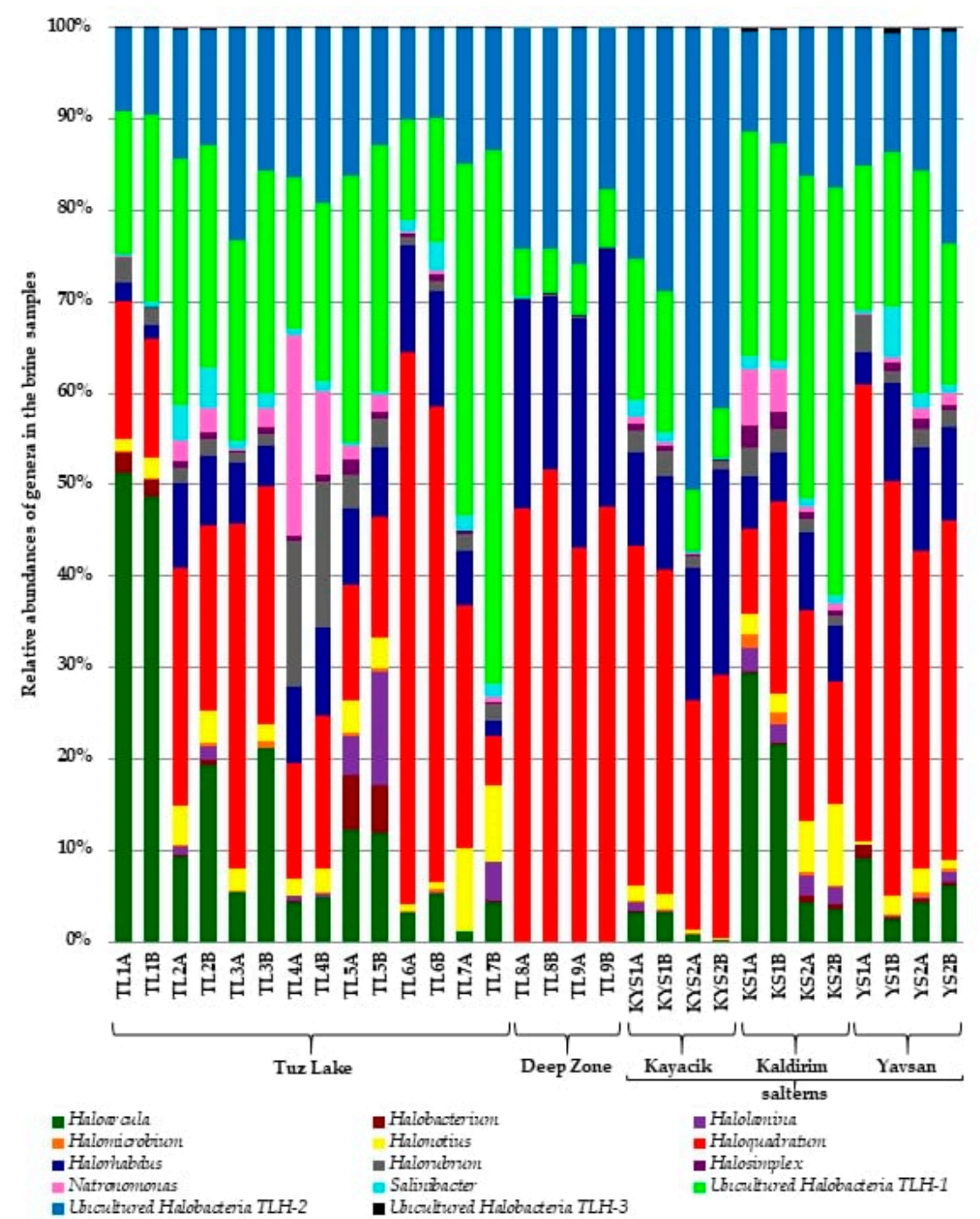

Figure 3. Taxonomic profiles at the genus level of prokaryotic communities detected in brine samples of Tuz Lake (TL1A to TL7B), Deep Zone (TL8A to TL9B), and Kayacik (KYS1A to KYS2B), Kaldirim (KS1A to KS2B), and Yavsan (YS1A to YS2B) salterns. Each OTU contains at least 1\% 16S rRNA sequence.

Haloquadratum (23.99\%) and Haloarcula $(14.36 \%)$ were determined as the most predominant genera in the brine samples of Tuz Lake, with the uncultured Halobacteria TLH-1 $(24.61 \%)$ as the most abundant taxon, and lower percentages for the representatives of the uncultured Halobacteria TLH-2 (13.98\%) and the archaeal genera Halorhabdus (6.90\%), Halorubrum (3.87\%), Halonotius (3.25\%), Natronomonas (3.00\%), Halolamina (1.73\%), and Halobacterium $(1.19 \%)$, and the bacterial genus Salinibacter $(1.54 \%)$ among those genera represented by at least $1 \%$ of the sequences (Table 2 ).

The Deep Zone samples were highlighted by a large presence of Haloquadratum (47.32\%), followed by Halorhabdus (23.76\%) and the uncultured Halobacteria TLH-2 (22.99\%). This last scenario is also repeated in Kayacik saltern samples, but in this case, the uncultured Halobacteria TLH-2 was more remarkable in these samples (36.18\%) than in the others. A similar composition was found in Yavsan saltern samples, but also uncultured Halobacteria TLH-1 showed a great abundance (17.93\%). In Kaldirim saltern, the most abundant taxon was the uncultured Halobacteria TLH-1, followed by Haloquadratum and the uncultured Halobacteria TLH-2. Finally, in contrast to Deep Zone and the other salterns, the genus Haloarcula was well represented in KS1 samples from Kaldirim saltern (Table 2 and Figure 3). 
In summary, concerning the domain Archaea, the genus Haloquadratum was always present and represented the most abundant taxon on most sampling sites (with percentages ranging from 47.32 to $16.57 \%$ ), while on the domain Bacteria, the genus Salinibacter was the only representative present at relatively low proportions (Table 2). Finally, two unknown and not yet isolated taxa, designated as uncultured Halobacteria TLH-1 and TLH-2, were predominant on Tuz Lake and Kaldirim saltern, and on Kayacik saltern, respectively (Table 2).

\subsection{Principal Components Analysis (PCA)}

Unweighted and weighted UniFrac, which are measurements of $\beta$-diversity, compare prokaryotic communities based on the phylogenetic relationships of the Archaea and Bacteria contained within communities. The PCA plot provides an overview visualization of the relationships of the communities among the samples [47-49]. UniFrac distances were generated using weighted and unweighted methods to compare the detected archaeal and bacterial communities of the brine samples collected from Tuz Lake, Deep Zone, and Kayacik, Kaldirim, and Yavsan salterns in terms of diversity among the samples and plotted them on PCA plots (Figure 4).

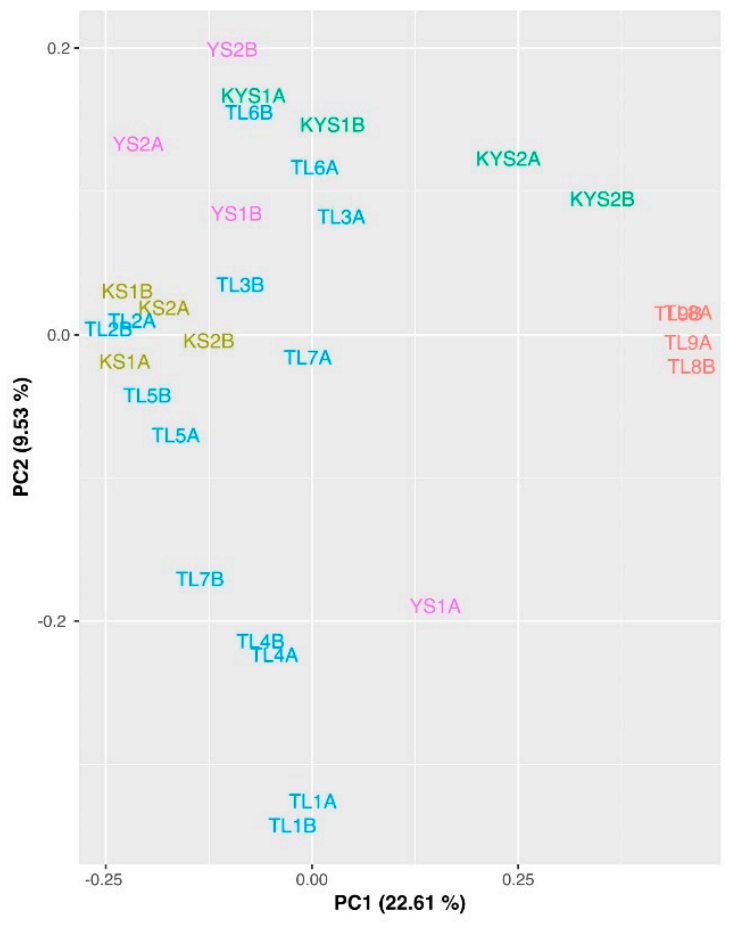

(A)

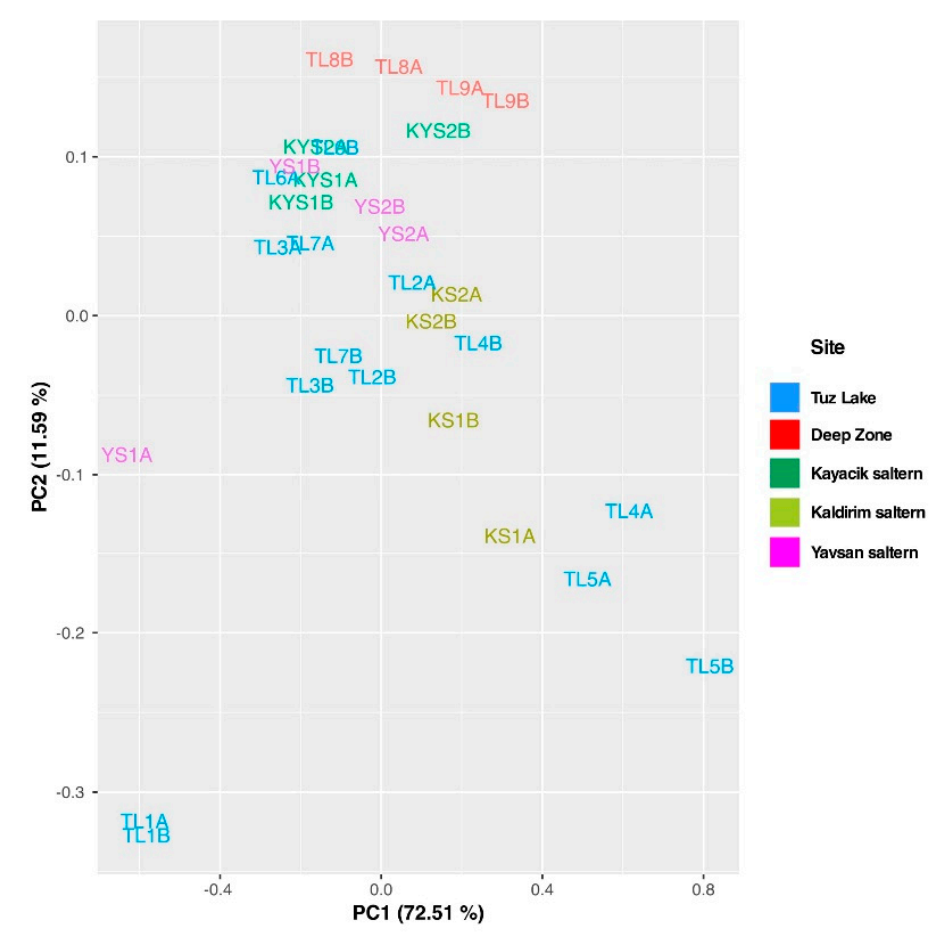

(B)

Figure 4. Principal components analysis (PCA) of the brine samples of Tuz Lake, Deep Zone, and Kayacik, Kaldirim, and Yavsan salterns. (A) Unweighted UniFrac, (B) Weighted UniFrac.

Figure 4 shows that the samples from each site were grouped relatively close to each other, except the sample YS1A with a more limited taxonomic diversity than the other samples from Yavsan saltern and the samples from Tuz Lake that were taken from different distant places due to the great extension of this lake. Especially, TL1 brine samples showed a greater difference in their variance compared to the rest of the brine samples collected from Tuz Lake.

A higher variance (84.1\%) was obtained from the weighted UniFrac PCA than the unweighted UniFrac PCA using the first two principal components. In this plot, five brine samples of Tuz Lake (TL1A, TL1B, TL4A, TL5A, and TL5B), and one brine sample of Yavsan (YS1A) saltern were not grouped closely with the other brine samples (Figure 4B). 


\subsection{Correlations among Genera}

The genera ( $>1 \%$ sequences) detected in the brine samples collected from Tuz Lake, Deep Zone, and Kayacik, Kaldirim, and Yavsan salterns and their statistical correlations were generated using R software version 3.6.2 (Figure 5). Diversity and abundance of the microbial communities changed according to positive and negative correlations among archaeal genera found in each sampling site $(p<0.05)$. Positive strong correlations were found between Halonotius and the uncultured Halobacteria TLH-1 ( $\mathrm{r}=0.917)$; genera Halorubrum and Natronomonas $(\mathrm{r}=0.857)$; and genera Halolamina and Halobacterium $(\mathrm{r}=0.676)$. Moreover, the genus Haloquadratum was found positively correlated with the genus Halorhabdus $(\mathrm{r}=0.582)$ and the uncultured Halobacteria TLH-2 $(\mathrm{r}=0.159)$. However, the increased presence of Haloquadratum, Halorhabdus, and the uncultured Halobacteria TLH-2 were negatively correlated with the abundance of the genera Haloarcula, Halobacterium, Halolamina, Halomicrobium, Halonotius, Halorubrum, Halosimplex, Natronomonas and the uncultured Halobacteria TLH-1. Although these genera had negative correlations with Haloquadratum, Halorhabdus and the uncultured Halobacteria TLH-2, in general, they had positive correlations with each other.

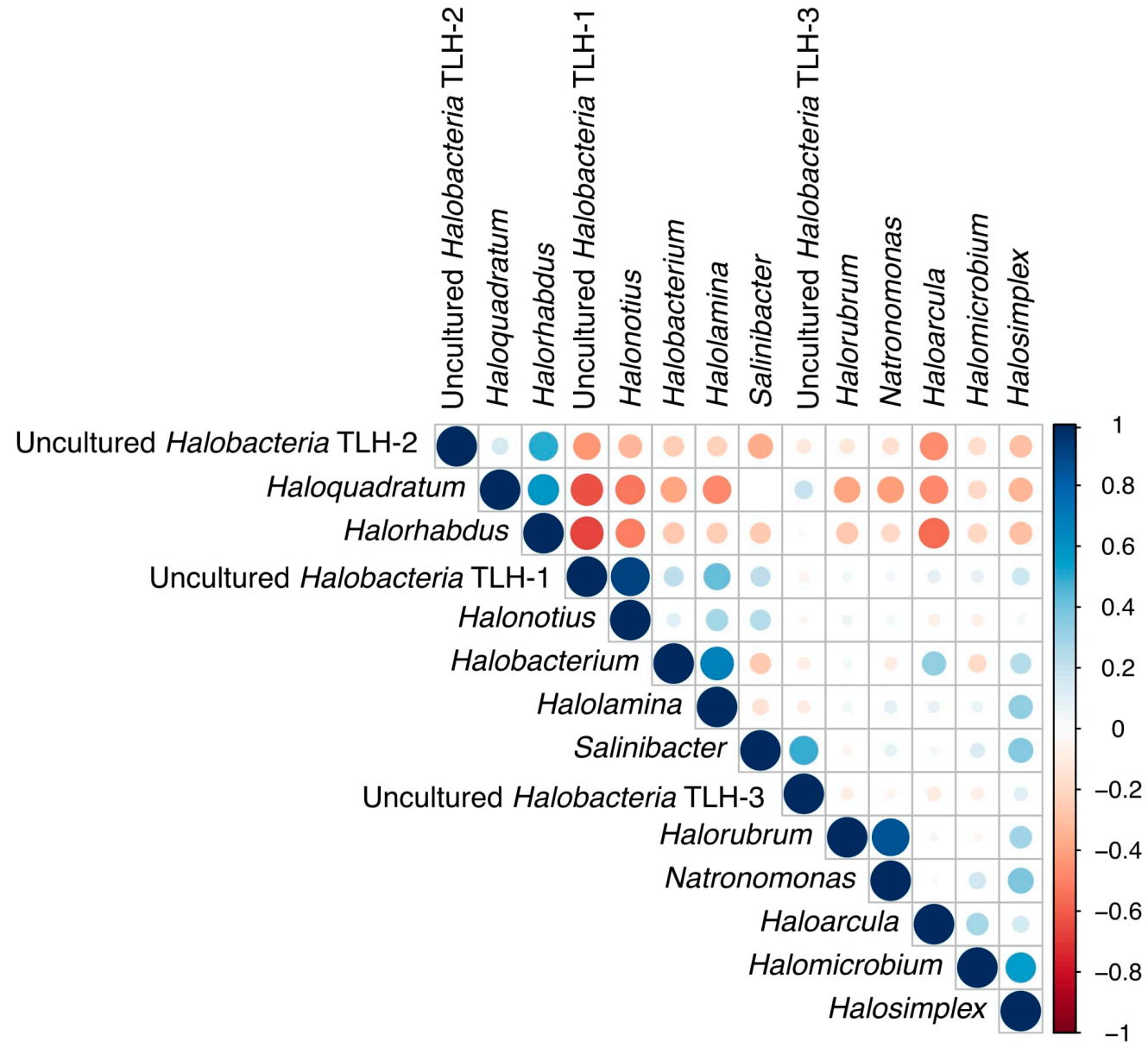

Figure 5. Statistical correlations among the genera with more than $1 \%$ sequences detected in Tuz Lake, Deep Zone, and Kayacik, Kaldirim, and Yavsan salterns.

\subsection{Correlations among Physico-Chemical Parameters and Brine Samples}

According to PCA analysis, eight physico-chemical variables (temperature, $\mathrm{pH}$, salinity, $\mathrm{Na}^{+}, \mathrm{K}^{+}, \mathrm{Mg}^{2+}, \mathrm{Ca}^{2+}$, and $\mathrm{Cl}^{-}$concentrations) were reduced to two principal components (Figure 6 and Table S3). Two principal components (Dim1 and Dim2) explained 79.8\% of the total variance. While the first component (Dim1) explained most of the variance 
(66.7\%), the second component (Dim2) explained $13.1 \%$ of the variance. While $\mathrm{pH}$, salinity, and sodium concentration were determined as the strongest parameters in the first component (Dim1), potassium concentration and temperature were in the second component (Dim2) (Table S3).

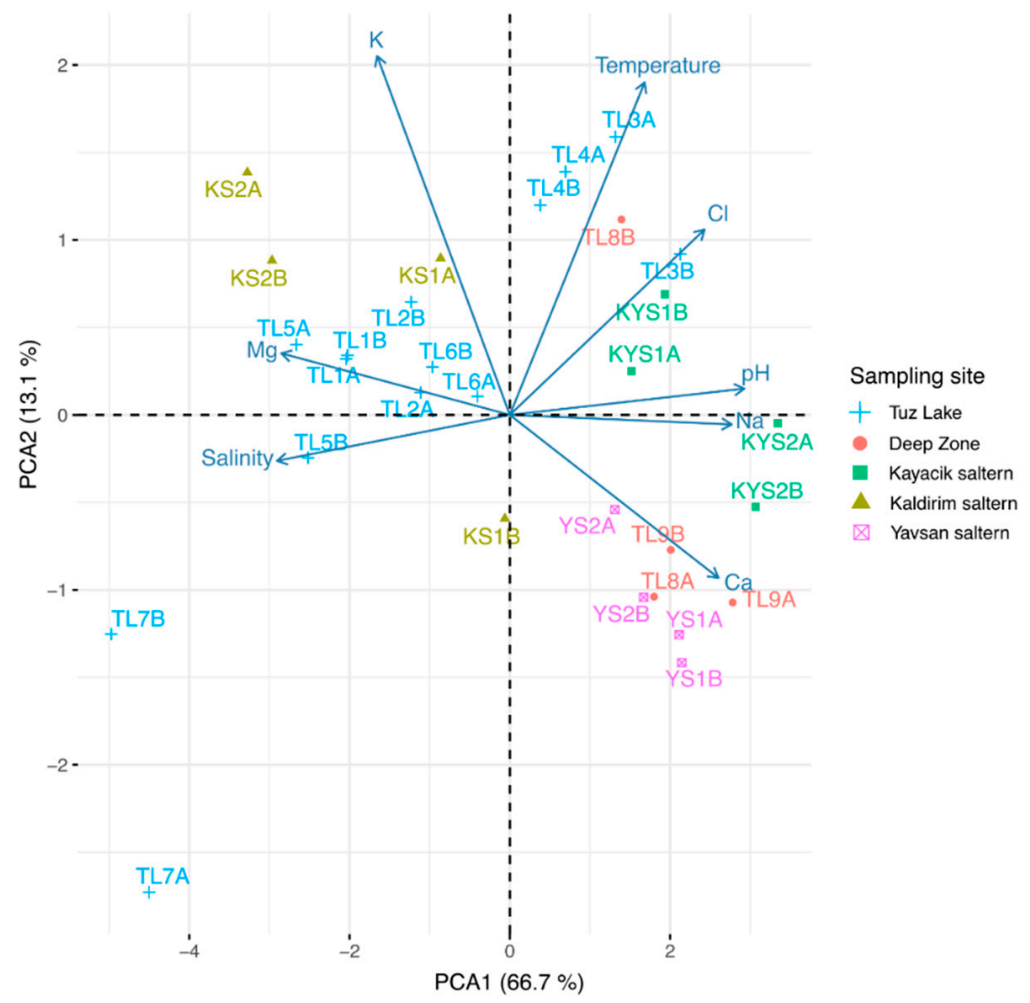

Figure 6. PCA biplot of Tuz Lake, Deep Zone, and Kayacik, Kaldirim, and Yavsan salterns' brine samples and physico-chemical parameters (blue arrows). The two PCA axes (Dim1 and Dim2) explained $79.8 \%$ of data variance. The brine samples are shown in the PCA biplot according to their relationship with the physico-chemical parameters.

As seen in Figure 6, samples of the Deep Zone, Kayacik (KYS2A-KYS2B), and Yavsan salterns were positively correlated to $\mathrm{Na}^{+}, \mathrm{Ca}^{2+}$, and $\mathrm{Cl}^{-}$concentrations, $\mathrm{pH}$, and temperature. Samples from Kaldirim saltern had a higher correlation to the increase of $\mathrm{K}^{+}$and $\mathrm{Mg}^{2+}$ concentrations and salinity.

However, TL7A and TL7B brine samples from Tuz Lake were especially located separately due to their different physico-chemical characteristics (Figure 6). Although this sampling site had high salinity and $\mathrm{Mg}^{2+}$ concentration, the temperature, $\mathrm{pH}, \mathrm{Na}^{+}$, $\mathrm{Ca}^{2+}$ and $\mathrm{Cl}^{-}$concentrations of this site were found to be low (Table S1). TL3A and TL4 brine samples from Tuz Lake had a strong positive correlation with temperature and $\mathrm{Cl}^{-}$ concentration, while TL1, TL2, and TL5 brine samples from Tuz Lake exhibited a positive correlation with salinity and $\mathrm{K}^{+}$and $\mathrm{Mg}^{2+}$ concentrations (Figure 6).

\section{Discussion}

The current study presents the physico-chemical analyses, including the ionic composition as well as the diversity and abundance of archaeal and bacterial communities in seven different areas of Tuz Lake and two different locations of the Deep Zone, and the three salterns located on the shore of the lake, namely Kayacik, Kaldirim, and Yavsan salterns in summer season, using $16 \mathrm{~S}$ rRNA gene based amplicon sequencing on Illumina platform. Furthermore, this study also offers the correlations among the genera and chemical analyses. 
Thalassohaline lakes derived from seawater are characterized by the predominance of sodium and chloride ions and a proportional composition of ions similar to that of seawater [2,50]. Besides, potassium, calcium, and magnesium are important cations, and fluoride, bromide, bicarbonate, and sulfate are important anions in thalassohaline lakes [51]. The ionic composition of Tuz Lake, containing potassium, calcium, magnesium as important cations, with a predominance of sodium and chloride ions (Table S1) unequivocally corroborates that this lake is a thalassohaline environment. Similar physico-chemical characteristics were determined in a recent study of this lake [31].

The high salinity $(\geq 30 \%)$ of Tuz Lake, Deep Zone, and the three salterns determined a very scarce prokaryotic diversity, showing in all of them a highly similar and restricted phyla composition, and a high dominance of the phylum Euryarchaeota. These data are in agreement with previous studies in Tuz Lake $[29,30]$ and in other thalassohaline environments, such as crystallizer ponds in Santa Pola (Spain) and other salterns (Spain) [36,52,53]. Besides, Halobacteria was the most abundant class in our study and several other thalassohaline lakes such as Great Salt Lake [54-56], Lake Tyrell [13,57,58], Aran-Bidgol salt lake [59], Lake Meyghan [60], and in the ponds of Santa Pola saltern [36,37,61] and Isla Cristina saltern in Spain [61,62].

In the present study, Haloquadratum (24\%) and Salinibacter (1.5\%) were respectively found as the most abundant archaeal and bacterial genera in Tuz Lake, the latter in a much lower proportion with respect to haloarchaea, but being the most relevant bacterial representative on these hypersaline habitats. Our data are in agreement with a previous study based on DGGE and 16S rRNA gene libraries of brine samples collected from two locations of the lake, in which Haloquadratum and Salinibacter were detected as the main genera [29]. The presence of representatives of the genera Halobacterium, Haloquadratum, Halorhabdus, and Halorubrum was noted in another study of Tuz Lake [30]. In the present study, a greater diversity was observed (Table 2 and Figure 3).

The dominant presence of the genus Haloquadratum was also observed in a $\mathrm{NaCl}$ saturated crystallizer pond (salinity 37\%) of Santa Pola saltern near Alicante (Spain) [36] and in the three salterns of Salitral Negro (SN), Colorada Grande (CG), and Guatraché (G) in Argentina [53]. Researchers stated that the genera Halorubrum and Haloquadratum were respectively found as the dominant taxa in marine salterns of Isla Cristina and Santa Pola (Spain) [61]. Furthermore, Haloquadratum, Haloarcula, Natronomonas, and Halorubrum were determined as the dominant genera in crystallizer ponds of Chula Vista salterns (salinity 32-35\%), near San Diego, California (U.S.A.) [63]. High abundance of Salinibacter in the hypersaline crystallizer ponds of Santa Pola salterns, Alicante (Spain) at salinities ranging from 19 to 37\% were also reported in previous studies [36,64-66]. Members of the extremely halophilic genus Salinibacter share the same habitats with the haloarchaeon Haloquadratum $[3,67]$. It has been emphasized that since the phages that infect Salinibacter were more active than the phages that infect Haloquadratum, the presence of Haloquadratum was found higher than that of Salinibacter in the environment [68]. The high prevalence of Haloquadratum in hypersaline environments may be related to the production of halomucin, which enables the growth of Haloquadratum walsbyi at the limits of water activity. Halomucin may protect Haloquadratum cells from cations and halophages found in hypersaline environments [69].

In addition to the dominance of Haloquadratum and a low abundance of Salinibacter, we also detected representatives of the genera Haloarcula and Halorhabdus in high abundance, and of the genera Halorubrum, Halonotius, Natronomonas, Halolamina, and Halobacterium in lower abundances in the Tuz Lake. Unlike previous studies carried out in this lake, we report for the first time the presence of two new dominant taxa belonging to uncultured Halobacteria and a third less abundant uncultured Halobacteria taxon (Table 2), contributing to the heterotrophic activity in this environment, but with unknown characteristics and functional activities in those habitats to be determined in future studies.

Currently, extremely halophilic archaea, also called haloarchaea, are taxonomically classified within Halobacteria, a class of the phylum Euryarchaeota, which are considered 
as the most halophilic microorganisms, growing from about $10 \%(w / v) \mathrm{NaCl}$ to saturated salt concentration. It consists of three orders: Halobacteriales, Haloferacales, and Natrialbales, which include six families and more than 50 genera $[5,70]$. A recent pan-genome analysis and ancestral state reconstruction of the class Halobacteria suggest a new super-order comprising of Natrialbales and Halobacteriales [71]. Our study in Tuz Lake has shown that eleven haloarchaeal genera are part of the microbiota of this environment (Table 2 and Figure 3), and that they are very diverse with respect to their taxonomic affiliations. In fact, these 11 genera are included in two different orders: Haloferacales and Halobacteriales. Representatives of the first order are placed on genera belonging to two different families: Haloferacaceae (genus Haloquadratum) and Halorubraceae (genera Halorubrum, Halonotius and Halolamina), while the order Halobacteriales included representatives placed on the families Halobacteriaceae (genera Halobacterium and Haloplanus) and Haloarculaceae (genera Haloarcula, Halorhabdus, Natronomonas, Halosimplex, and Halomicrobium). This is a much diverse archaeal community than those observed previously in this lake and several other similar thalassohaline lakes.

In the present study, we determined a lower diversity of extremely halophilic archaea in the Deep Zone (Table 2 and Figure 3), which contained higher $\mathrm{Na}^{+}$and $\mathrm{Cl}^{-}$concentrations compared to the other sampling sites (Table S1). Haloquadratum is considered the most hyperhalophilic organism known and dominates $\mathrm{NaCl}$ supersaturated thalassic lakes where the other halophilic archaea are eliminated by the uninhabitable conditions [72]. Moreover, the concentration of $\mathrm{NaCl}$ in the crystallizer ponds due to evaporation of the saline water finally results in the precipitation of sodium chloride (halite); consequently, a $\mathrm{MgCl}_{2}$ rich brine is produced. Before the magnesium chloride brines get sterile, Haloquadratum dominates and can make up to almost $80 \%$ of the total microbial biomass $[36,37,61,73]$. Therefore, at extremely high salinity, some essential nutrients (e.g., phosphates) become unavailable due to complexation with $\mathrm{Mg}^{2+}$ [74]. The chemical composition of the water in the Deep Zone is significantly different with respect to Tuz Lake, which may affect the precipitation reactions; $\mathrm{Ca}$ and $\mathrm{Mg}$ precipitates are formed in the Deep Zone [75]. In our study, while mean values of $\mathrm{Na}^{+}, \mathrm{Ca}^{2+}$, and $\mathrm{Cl}^{-}$concentrations of the Deep Zone were found to be higher than that of the Tuz Lake, mean values of $\mathrm{K}^{+}$and $\mathrm{Mg}^{2+}$ concentrations were lower than that of the lake. These data support the above-mentioned conclusions of Bolhuis et al. [74] and indicate that some of the essential nutrients may be biologically unavailable in the Deep Zone, causing the selection of some extreme halophiles. Therefore, we suppose that the high $\mathrm{Na}^{+}$concentrations and the deficiency of some essential nutrients in the Deep Zone support less diverse extremely halophilic archaeal populations and almost all sequences from the Deep Zone belonged to the OTUs classified as representatives of the genera Haloquadratum and Halorhabdus, and the uncultured Halobacteria TLH-2 (Figure 3). In addition, it is obvious that the halophilic diversity in the Deep Zone is not affected by the lake because the sill in the north-south direction has separated the Deep Zone from the main lake as the water level has decreased over the recent years.

On the other hand, another factor that could influence the haloarchaeal taxonomic composition of hypersaline habitats is the extracellular DNA metabolism by some haloarchaea. Hypersaline aquatic environments have been reported to contain high extracellular DNA concentrations and that DNA can be used primarily as a phosphorus source. DNA is utilized selectively as a phosphorus source, with a bias against highly divergent methylated DNA [76]. Recent studies by Hua et al. [77] have shown that microbial communities of Isla Cristina saltern (Spain) utilized extracellular DNA only as a phosphorus source and that the taxonomic composition of these communities changed with the availability of inorganic phosphorus or extracellular DNA, with preferential uptake of extracellular DNA from specific haloarchaeal taxa, especially from the most abundant ones. These authors concluded that some haloarchaea prefer extracellular DNA from closely related taxa and that the microbial community assembly is driven by the available resources, including carbon, extracellular DNA, and inorganic phosphorus [77]. 
In the present study, the genus Haloquadratum demonstrated a negative correlation with all haloarchaeal genera (except the genus Halorhabdus) and the unclassified Halobacteria OTU-1 (Figure 5). This is in agreement with the negative correlation of the genus Haloquadratum with the genera Haloarcula, Halobaculum, Halorubrum, Halonotius, and Salinibacter determined in Lake Tyrrell in Australia [58].

The presence and abundance of representatives of the haloarchaeal genera in Tuz Lake, its salterns, and the Deep Zone may have also been affected by halocins produced by archaeal strains in this habitat. Halocins are natural proteinaceous antimicrobials that were first discovered by Rodríguez-Valera et al. [78] and are commonly produced by haloarchaea [79]. In previous studies, we detected that the halocin production by archaeal populations in Tuz Lake and Kaldirim and Kayacik salterns were a common feature [80,81]. It has been emphasized that halocins reduce the competition with other prokaryotes by lysing competitors and enriching the environment for the producer strains [78].

\section{Conclusions}

In this study, we describe the first detailed data on the prokaryotic communities of different areas of Tuz Lake, as well as its Deep Zone and the three salterns located on the shores of the largest hypersaline lake in Turkey, by using 16S rRNA amplicon sequencing (Illumina chemistry). The high salinity (30-38\%) and other physico-chemical and environmental characteristics of the sampling sites studied limit the diversity of these hypersaline habitats, with extremely halophilic archaea as the dominant population, and to a lesser extent, a few bacterial representatives, with the extremely halophilic bacterial genus Salinibacter as the main taxon found in all samples analyzed. Prokaryotic diversity (archaea and bacteria) of the sampling sites was determined in the summer season, with high radiation and desiccation, and despite the high extension of the area studied, a similar microbial composition was found among samples.

Besides the high abundance of representatives of the haloarchaeal genus Haloquadratum, determined in all sampling areas, especially in Tuz Lake (24\%) and the Deep Zone (47\%), and Yavsan (41\%) and Kayacik (31\%) salterns, other haloarchaeal genera were also determined in these extreme habitats: Haloarcula, Halorhabdus, Halorubrum, Halonotius, Natronomonas, Halolamina, Halobacterium, Halosimplex, Halomicrobium, and Haloplanus. It is noteworthy that, besides sequences related to previously described taxa, two uncultured extremely halophilic microorganisms designated as uncultured Halobacteria TLHs 1 and 2 were found to be very abundant, especially in Tuz Lake, Kaldirim saltern, and Deep Zone and Kayacik saltern, respectively. Their isolation in pure culture would give focus to their role and functional activities on these natural environments and their possible use in industrial processes and as bioindicators of environmental changes or pollution increases in this habitat, that despite being a protected area, it is relatively close to industrial and human-inhabited zones. Therefore, further research is required to determine the features of these uncultured taxa, the isolation of new strains using novel growth media and culture conditions, permitting the isolation of these extremely halophilic microorganisms, and elucidating their ecological role in these natural habitats, as well as to explore their biotechnological and biomedical potentials.

Supplementary Materials: The following are available online at https: / www.mdpi.com/article / 10.3390/microorganisms9071525/s1. Table S1: Environmental parameters and physico-chemical analyses results of 30 brine samples collected from Tuz Lake (TL1A to TL7B), Deep Zone (TL8A to TL9B), and Kayacik (KYS1A to KYS2B), Kaldirim (KS1A to KS2B), and Yavsan (YS1A to YS2B) salterns. Table S2: Mean percentages of phyla composition of brine samples collected from Tuz Lake, Deep Zone, and Kayacik, Kaldirim, and Yavsan salterns. Table S3: Principal component analysis of physico-chemical parameters. Figure S1: Rarefaction curves plotting the number of observed OTUs as a function of the number of sequences.

Author Contributions: Conceptualization, C.A., M.B. and A.V.; methodology, C.A., A.B.F., P.C., B.C., M.B. and A.V.; software, C.A. and A.B.F.; validation, C.A., A.B.F., P.C., B.C., M.B. and A.V.; formal analysis, C.A., A.B.F., P.C., B.C., M.B. and A.V.; investigation, C.A., P.C., M.B. and B.C.; resources, 
M.B. and A.V.; data curation, C.A. and A.B.F.; writing-original draft preparation, C.A., A.B.F., M.B., B.C. and A.V.; writing-review and editing, C.A., A.B.F., P.C., B.C., M.B. and A.V.; visualization, C.A., A.B.F., P.C., B.C., M.B. and A.V.; supervision, M.B. and A.V.; project administration, M.B.; funding acquisition, M.B. and A.V. All authors have read and agreed to the published version of the manuscript.

Funding: This research was funded by the FEDER/Spanish Ministry of Science and Innovation-State Research Agency (project CGL2017-83385-P), and Junta de Andalucía (grants BIO-213 and US1263771), Spain, which included FEDER funds (to A.V.). This work was also funded by the Marmara University Scientific Research Projects Commission (Project Number: FEN-C-DRP-120417-0186).

Institutional Review Board Statement: Not applicable.

Informed Consent Statement: Not applicable.

Data Availability Statement: Sequence data are available at the European Nucleotide Archive (ENA)/NCBI, study accession number PRJNA705280.

Acknowledgments: The authors would like to express their gratitude to Marmara University Scientific Research Projects Commission (BAPKO) for funding. We also thank Ahmet Ismailoglu, Ahmet Solak, Birol Mutlu, Emrah Keskinsoy, Erdem Can, Fatih Haktan, Ilker Ozkececigil, Muharrem Durukan, Muzaffer Mutlu, Ozan Atilgan, Tufan Gok, and Yusuf Sinan Dogan for helping with the collection of samples. We are grateful to Hatice Yesil for helping with some of the physico-chemical analyses of the brine samples.

Conflicts of Interest: The authors declare no conflict of interest.

\section{References}

1. Rodríguez-Valera, F. Characteristics and microbial ecology of hypersaline environments. In Halophilic Bacteria; Rodríguez-Valera, F., Ed.; CRC Press: Boca Raton, FL, USA, 1988; Volume 1, pp. 3-30.

2. Ventosa, A. Unusual micro-organisms from unusual habitats: Hypersaline environments. In Prokaryotic Diversity: Mechanisms and Significance; Society for General Microbiology Symposia, Logan, N.A., Lappin-Scott, H.M., Oyston, P.C.F., Eds.; Cambridge University Press: Cambridge, UK, 2006; Volume 66, pp. 223-254.

3. Ventosa, A.; Fernández, A.B.; León, M.J.; Sánchez-Porro, C.; Rodríguez-Valera, F. The Santa Pola saltern as a model for studying the microbiota of hypersaline environments. Extremophiles 2014, 18, 811-824. [CrossRef] [PubMed]

4. Ventosa, A.; de la Haba, R.R.; Sánchez-Porro, C.; Papke, R.T. Microbial diversity of hypersaline environments: A metagenomic approach. Curr. Opin. Microbiol. 2015, 25, 80-87. [CrossRef] [PubMed]

5. Amoozegar, M.A.; Siroosi, M.; Atashgahi, S.; Smidt, H.; Ventosa, A. Systematics of haloarchaea and biotechnological potential of their hydrolytic enzymes. Microbiology 2017, 163, 623-645. [CrossRef] [PubMed]

6. Vera-Gargallo, B.; Ventosa, A. Metagenomic insights into the phylogenetic and metabolic diversity of the prokaryotic community dwelling in hypersaline soils from the odiel saltmarshes (SW Spain). Genes 2018, 9, 152. [CrossRef] [PubMed]

7. Vera-Gargallo, B.; Chowdhury, T.R.; Brown, J.; Fansler, S.J.; Durán-Viseras, A.; Sánchez-Porro, C.; Bailey, V.L.; Jansson, J.K.; Ventosa, A. Spatial distribution of prokaryotic communities in hypersaline soils. Sci. Rep. 2019, 9, 1769. [CrossRef]

8. La Cono, V.; Bortoluzzi, G.; Messina, E.; La Spada, G.; Smedile, F.; Giuliano, L.; Borghini, M.; Stumpp, C.; Schmitt-Kopplin, P.; Harir, M.; et al. The discovery of Lake Hephaestus, the youngest athalassohaline deep-sea formation on Earth. Sci. Rep. 2019, 9 , 8031. [CrossRef]

9. Javor, B.J. Hypersaline Environments: Microbiology and Biogeochemistry; Springer: Berlin, Germany, 1989.

10. Grant, W.D. General view of halophiles. In Superbugs. Microorganisms in Extreme Environments; Horikoshi, K., Grant, W.D., Eds.; Springer: Tokyo, Japan, 1990; pp. 15-37.

11. Oren, A. Halophilic Microorganisms and Their Environments; Kluwer Scientific Publishers: Dordrecht, The Netherlands, 2002.

12. Pagaling, E.; Wang, H.; Venables, M.; Wallace, A.; Grant, W.D.; Cowan, D.A.; Jones, B.E.; Ma, Y.; Ventosa, A.; Heaphy, S. Microbial biogeography of six salt lakes in Inner Mongolia, China, and a salt lake in Argentina. Appl. Environ. Microbiol. 2009, 75, 5750-5760. [CrossRef] [PubMed]

13. Podell, S.; Ugalde, J.A.; Narasingarao, P.; Banfield, J.F.; Heidelberg, K.B.; Allen, E.E. Assembly-driven community genomics of a hypersaline microbial ecosystem. PLoS ONE 2013, 8, e61692. [CrossRef]

14. Cavicchioli, R. Microbial ecology of Antarctic aquatic systems. Nat. Rev. Microbiol. 2015, 13, 691-706. [CrossRef]

15. Oren, A. Life at high salt concentrations. In The Prokaryotes; Rosenberg, E., DeLong, E.F., Lory, S., Stackebrandt, E., Thompson, F., Eds.; Springer: Berlin/Heidelberg, Germany, 2013; pp. 421-440.

16. Amoozegar, M.A.; Safarpour, A.; Noghabi, K.A.; Bakhtiary, T.; Ventosa, A. Halophiles and their vast potential in biofuel production. Front. Microbiol. 2019, 10, 1895. [CrossRef]

17. Corral, P.; Amoozegar, M.A.; Ventosa, A. Halophiles and their biomolecules: Recent advances and future applications in biomedicine. Mar. Drugs 2020, 18, 33. [CrossRef] 
18. Çınar, S.; Mutlu, M.B. Prokaryotic community compositions of the hypersaline sediments of Tuz Lake demonstrated by cloning and high-throughput sequencing. Microbiology 2020, 89, 756-768. [CrossRef]

19. Tuz Lake Special Environmental Protection Area Management Plan (2014-2018); Directorate General for Preservation of Natural Heritage; Tuz Lake Special Environmental Protection Area Management Plan, 2014-2018.

20. Erol, O. Tuz Gölü Havzasının jeolojisi ve jeomorfolojisi. Mineral Research and Exploration Institute of Turkey (MTA) Report No. 4220. 1969. (In Turkish)

21. Kilic, O.; Kilic, A.M. Salt crust mineralogy and geochemical evolution of the Salt Lake (Tuz Gölü), Turkey. Sci. Res. Essays 2010, 5, 1317-1324.

22. Birbir, M.; Calli, B.; Mertoglu, B.; Bardavid, R.E.; Oren, A.; Ogmen, M.N.; Ogan, A. Extremely halophilic Archaea from Tuz Lake, Turkey, and the adjacent Kaldirim and Kayacik salterns. World J. Microbiol. Biotechnol. 2007, 23, 309-316. [CrossRef]

23. Karakaya, M.Ç.; Bozdă̆, A.; Ercan, H.Ü.; Karakaya, N.; Delikan, A. Origin of Miocene halite from Tuz Gölü basin in Central Anatolia, Turkey: Evidences from the pure halite and fluid inclusion geochemistry. J. Geochem. Explor. 2019, 202, 1-12. [CrossRef]

24. TVKGM. Official Website of Directorate General for Preservation of Natural Heritage. Available online: https:/ tvk.csb.gov.tr/ (accessed on 15 February 2021).

25. Aksoz, N.; Kolonkaya, N. Ilımlı tuzcul karakterli bir bakterinin Tuz Gölünden (Türkiye) izolasyonu. Mikrobiyol. Bull. 1984, 18, 107-113.

26. Birbir, M.; Kalli, N.; Johannson, C. Examination of salt quality of Sereflíkoçhísar Lake used in the Turkish leather industry. J. Soc. Leath. Tech. Ch. 2002, 86, 112-117.

27. Birbir, M.; Sesal, C. Extremely halophilic bacterial communities in Şereflikoçhisar Salt Lake in Turkey. Turk. J. Biol. 2003, 27, 7-22.

28. Ozcan, B.; Ozcengiz, G.; Coleri, A.; Cokmus, C. Diversity of halophilic archaea from six hypersaline environments in Turkey. J. Microbiol. Biotechnol. 2007, 17, 985-992.

29. Mutlu, M.B.; Martínez-García, M.; Santos, F.; Peña, A.; Guven, K.; Antón, J. Prokaryotic diversity in Tuz Lake, a hypersaline environment in Inland Turkey. FEMS Microbiol. Ecol. 2008, 65, 474-483. [CrossRef]

30. Ünal, H.; Kücükyildirim, S. Metabarkodlama Metabarkodlama yaklaşımıyla Tuz Gölü, Türkiye mikroorganizmalarının belirlenmesi için bir pilot çalışma. EJOSAT 2020, 366-374. Available online: https://dergipark.org.tr/en/download/article-file/1153358 (accessed on 13 July 2021).

31. Oyewusi, H.A.; Abdul Wahab, R.; Edbeib, M.F.; Mohamad, M.A.N.; Abdul Hamid, A.A.; Kaya, Y.; Huyop, F. Functional profiling of bacterial communities in Lake Tuz using 16S rRNA gene sequences. Biotechnol. Biotechnol. Equip. 2021, 35, 1-10. [CrossRef]

32. Çınar, S.; Mutlu, M.B. Assessing the diversity of prokaryotic communities and nanohaloarchaeal lineages in various aquatic hypersaline habitats (Turkey) using high-throughput sequencing and cloning. Eskişehir Teknik Üniversitesi Bilim Teknoloji Dergisi-C Yaşam Bilimleri Biyoteknoloji 2021, 10, 57-68. [CrossRef]

33. Clarke, F.E. Determination of chloride in water improved colorimetric and titrimetric methods. Anal. Chem. 1950, 22, 553-555. [CrossRef]

34. APHA. Standard Methods for the Examination of Water and Wastewater, 21st ed.; American Public Health Association: Washington, DC, USA, 2005.

35. Yesil, H.; Tugtas, A.E. Removal of heavy metals from leaching effluents of sewage sludge via supported liquid membranes. Sci. Total Environ. 2019, 693, 133608. [CrossRef] [PubMed]

36. Ghai, R.; Pašić, L.; Fernández, A.B.; Martin-Cuadrado, A.B.; Mizuno, C.M.; McMahon, K.D.; Papke, R.T.; Stepanauskas, R.; Rodriguez-Brito, B.; Rohwer, F.; et al. New abundant microbial groups in aquatic hypersaline environments. Sci. Rep. $2011,1,135$. [CrossRef]

37. Fernández, A.B.; Ghai, R.; Martin-Cuadrado, A.B.; Sánchez-Porro, C.; Rodríguez-Valera, F.; Ventosa, A. Prokaryotic taxonomic and metabolic diversity of an intermediate salinity hypersaline habitat assessed by metagenomics. FEMS Microbiol. Ecol. 2014, 88, 623-635. [CrossRef]

38. Vavourakis, C.D.; Ghai, R.; Rodríguez-Valera, F.; Sorokin, D.Y.; Tringe, S.G.; Hugenholtz, P.; Muyzer, G. Metagenomic insights into the uncultured diversity and physiology of microbes in four hypersaline soda lake brines. Front. Microbiol. $2016,7,211$. [CrossRef]

39. Klindworth, A.; Pruesse, E.; Schweer, T.; Peplies, J.; Quast, C.; Horn, M.; Glöckner, F.O. Evaluation of general 16S ribosomal RNA gene PCR primers for classical and next-generation sequencing-based diversity studies. Nucleic Acids Res. 2013, 41, e1. [CrossRef]

40. Tremblay, J.; Singh, K.; Fern, A.; Kirton, E.S.; He, S.; Woyke, T.; Lee, J.; Chen, F.; Dangl, J.L.; Tringe, S.G. Primer and platform effects on 16S rRNA tag sequencing. Front. Microbiol. 2015, 6, 771. [CrossRef]

41. Babraham Bioinformatics FastQC A Quality Control Tool for High Throughput Sequence Data. Available online: https://www. bioinformatics.babraham.ac.uk/projects/fastqc/ (accessed on 15 February 2021).

42. Caporaso, J.G.; Kuczynski, J.; Stombaugh, J.; Bittinger, K.; Bushman, F.D.; Costello, E.K.; Fierer, N.; Peña, A.G.; Goodrich, J.K.; Gordon, J.I.; et al. QIIME allows analysis of high-throughput community sequencing data. Nat. Methods 2010, 7, 335-336. [CrossRef]

43. Edgar, R.C. Search and clustering orders of magnitude faster than BLAST. Bioinformatics 2010, 26, 2460-2461. [CrossRef]

44. DeSantis, T.Z.; Hugenholtz, P.; Larsen, N.; Rojas, M.; Brodie, E.L.; Keller, K.; Huber, T.; Dalevi, D.; Hu, P.; Andersen, G.L. Greengenes, a chimera-checked $16 \mathrm{~S}$ rRNA gene database and workbench compatible with ARB. Appl. Environ. Microbiol. 2006, 72, 5069-5072. [CrossRef] 
45. Haas, B.J.; Gevers, D.; Earl, A.M.; Feldgarden, M.; Ward, D.V.; Giannoukos, G.; Ciulla, D.; Tabbaa, D.; Highlander, S.K.; Sodergren, E.; et al. Chimeric 16S rRNA sequence formation and detection in Sanger and 454-pyrosequenced PCR amplicons. Genome Res. 2011, 21, 494-504. [CrossRef]

46. Venables, W.N.; Ripley, B.D. Modern Applied Statistics with S-Plus, 1994th ed.; Springer: New York, NY, USA, 2013.

47. Lozupone, C.; Lladser, M.E.; Knights, D.; Stombaugh, J.; Knight, R. UniFrac: An effective distance metric for microbial community comparison. ISME J. 2011, 5, 169-172. [CrossRef] [PubMed]

48. Roldán Ahumada, J.A.; Avendaño Garrido, M.L. A commentary on diversity measures UniFrac in very small sample size. Evol. Bioinform. 2019, 15, 1-9. [CrossRef] [PubMed]

49. Knecht, V.R.; McGinniss, J.E.; Shankar, H.M.; Clarke, E.L.; Kelly, B.J.; Imai, I.; Fitzgerald, A.S.; Bittinger, K.; Bushman, F.D.; Collman, R.G. Molecular analysis of bacterial contamination on stethoscopes in an intensive care unit. Infect. Control Hosp. Epidemiol. 2019, 40, 171-177. [CrossRef]

50. Grant, W.D. Life at low water activity. Philos. Trans. R. Soc. Lond. B Biol. Sci. 2004, 359, 1249-1267. [CrossRef]

51. Ventosa, A.; Arahal, D.R. Physico-chemical characteristics of hypersaline environments and their biodiversity. Extremophiles 2009, 2, 247-262.

52. Fernández, A.B.; Ghai, R.; Martin-Cuadrado, A.B.; Sánchez-Porro, C.; Rodríguez-Valera, F.; Ventosa, A. Metagenome sequencing of prokaryotic microbiota from two hypersaline ponds of a marine saltern in Santa Pola, Spain. Genome Announc. 2013, 1, e00933-13. [CrossRef] [PubMed]

53. Di Meglio, L.; Santos, F.; Gomariz, M.; Almansa, C.; López, C.; Antón, J.; Nercessian, D. Seasonal dynamics of extremely halophilic microbial communities in three Argentinian salterns. FEMS Microbiol. Ecol. 2016, 92, 1-15. [CrossRef]

54. Baxter, B.K.; Litchfield, C.D.; Sowers, K.; Griffith, J.D.; Dassarma, P.A.; Dassarma, S. Microbial Diversity of Great Salt Lake. In Adaptation to Life at High Salt Concentrations in Archaea, Bacteria, and Eukarya; Gunde-Cimerman, N., Oren, A., Plemenitaš, A., Eds.; Springer: Dordrecht, The Netherlands, 2005; Volume 9, pp. 9-25.

55. Almeida-Dalmet, S.; Sikaroodi, M.; Gillevet, P.M.; Litchfield, C.D.; Baxter, B.K. Temporal study of the microbial diversity of the North Arm of Great Salt Lake, Utah, U.S. Microorganisms 2015, 3, 310-326. [CrossRef]

56. Baxter, B.K.; Zalar, P. The extremophiles of Great Salt Lake: Complex microbiology in a dynamic hypersaline ecosystem. In Model Ecosystems in Extreme Environments; Elsevier: Amsterdam, The Netherlands, 2019; pp. 57-99.

57. Narasingarao, P.; Podell, S.; Ugalde, J.A.; Brochier-Armanet, C.; Emerson, J.B.; Brocks, J.J.; Heidelberg, K.B.; Banfield, J.F.; Allen, E.E. De novo metagenomic assembly reveals abundant novel major lineage of Archaea in hypersaline microbial communities. ISME J. 2012, 6, 81-93. [CrossRef] [PubMed]

58. Podell, S.; Emerson, J.B.; Jones, C.M.; Ugalde, J.A.; Welch, S.; Heidelberg, K.B.; Banfield, J.F.; Allen, E.E. Seasonal fluctuations in ionic concentrations drive microbial succession in a hypersaline lake community. ISME J. 2014, 8, 979-990. [CrossRef] [PubMed]

59. Makhdoumi-Kakhki, A.; Amoozegar, M.A.; Kazemi, B.; Pašić, L.; Ventosa, A. Prokaryotic diversity in Aran-Bidgol salt lake, the largest hypersaline playa in Iran. Microbes Environ. 2012, 27, 87-93. [CrossRef] [PubMed]

60. Naghoni, A.; Emtiazi, G.; Amoozegar, M.A.; Cretoiu, M.S.; Stal, L.J.; Etemadifar, Z.; Shahzadeh Fazeli, S.A.; Bolhuis, H. Microbial diversity in the hypersaline Lake Meyghan, Iran. Sci. Rep. 2017, 7, 1-13. [CrossRef] [PubMed]

61. Fernández, A.B.; Vera-Gargallo, B.; Sánchez-Porro, C.; Ghai, R.; Papke, R.T.; Rodríguez-Valera, F.; Ventosa, A. Comparison of prokaryotic community structure from Mediterranean and Atlantic saltern concentrator ponds by a metagenomic approach. Front. Microbiol. 2014, 5, 1-12. [CrossRef]

62. Fernández, A.B.; León, M.J.; Vera, B.; Sánchez-Porro, C.; Ventosa, A. Metagenomic sequence of prokaryotic microbiota from an intermediate-salinity pond of a saltern in Isla Cristina, Spain. Genome Announc. 2014, 2, 1-2. [CrossRef]

63. Pasić, L.; Rodríguez-Mueller, B.; Martin-Cuadrado, A.B.; Mira, A.; Rohwer, F.; Rodríguez-Valera, F. Metagenomic islands of hyperhalophiles: The case of Salinibacter ruber. BMC Genom. 2009, 10, 570. [CrossRef]

64. Antón, J.; Llobet-Brossa, E.; Rodríguez-Valera, F.; Amann, R. Fluorescence in situ hybridization analysis of the prokaryotic community inhabiting crystallizer ponds. Environ. Microbiol. 1999, 1, 517-523. [CrossRef]

65. Benlloch, S.; López-López, A.; Casamayor, E.O.; Øvreås, L.; Goddard, V.; Daae, F.L.; Smerdon, G.; Massana, R.; Joint, I.; Thingstad, F.; et al. Prokaryotic genetic diversity throughout the salinity gradient of a coastal solar saltern. Environ. Microbiol. 2002, 4, 349-360. [CrossRef] [PubMed]

66. Legault, B.A.; Lopez-Lopez, A.; Alba-Casado, J.C.; Doolittle, W.F.; Bolhuis, H.; Rodríguez-Valera, F.; Papke, R.T. Environmental genomics of "Haloquadratum walsbyi" in a saltern crystallizer indicates a large pool of accessory genes in an otherwise coherent species. BMC Genom. 2006, 7, 171. [CrossRef] [PubMed]

67. Antón, J.; Peña, A.; Santos, F.; Martínez-García, M.; Schmitt-Kopplin, P.; Rosselló-Mora, R. Distribution, abundance and diversity of the extremely halophilic bacterium Salinibacter ruber. Saline Syst. 2008, 4, 15. [CrossRef]

68. Ma, Y.; Galinski, E.A.; Grant, W.D.; Oren, A.; Ventosa, A. Halophiles 2010: Life in saline environments. Appl. Environ. Microbiol. 2010, 76, 6971-6981. [CrossRef] [PubMed]

69. Zenke, R.; von Gronau, S.; Bolhuis, H.; Gruska, M.; Pfeiffer, F.; Oesterhelt, D. Fluorescence microscopy visualization of halomucin, a secreted $927 \mathrm{kDa}$ protein surrounding Haloquadratum walsbyi cells. Front. Microbiol. 2015, 6, 249. [CrossRef] [PubMed]

70. Oren, A.; Ventosa, A.; Kamekura, M. Class Halobacteria. In Bergey's Manual of Systematics of Archaea and Bacteria; Whitman, W.B., Ed.; Whiley \& Sons: Hoboken, NJ, USA, 2017; pp. 1-5. 
71. Gaba, S.; Kumari, A.; Medema, M.; Kaushik, R. Pan-genome analysis and ancestral state reconstruction of class halobacteria: Probability of a new super-order. Sci. Rep. 2020, 10, 21205. [CrossRef] [PubMed]

72. Bolhuis, H.; Martín-Cuadrado, A.B.; Rosselli, R.; Pašić, L.; Rodríguez-Valera, F. Transcriptome analysis of Haloquadratum walsbyi: Vanity is but the surface. BMC Genom. 2017, 18, 510. [CrossRef]

73. Bolhuis, H.; Poele, E.M.T.; Rodríguez-Valera, F. Isolation and cultivation of Walsby's square archaeon. Environ. Microbiol. 2004, 6, 1287-1291. [CrossRef] [PubMed]

74. Bolhuis, H.; Palm, P.; Wende, A.; Falb, M.; Rampp, M.; Rodríguez-Valera, F.; Pfeiffer, F.; Oesterhelt, D. The genome of the square archaeon Haloquadratum walsbyi: Life at the limits of water activity. BMC Genom. 2006, 7, 169. [CrossRef]

75. Uygun, A.; Şen, E. The Salt Lake basin and natural resources I: Geochemistry of the brine of the Salt Lake (Central Anatolia-Turkey). Bull. Geol. Soc. Turk. 1978, 21, 113-120.

76. Chimileski, S.; Dolas, K.; Naor, A.; Gophna, U.; Papke, R.T. Extracellular DNA metabolism in Haloferax volcanii. Front. Microbiol. 2014, 5, 57. [CrossRef]

77. Hua, Z.; Ouellette, M.; Makkay, A.M.; Papke, R.T.; Zhaxybayeva, O. Nutrient supplementation experiments with saltern microbial communities implicate utilization of DNA as a source of phosphorus. ISME J. 2021, 1-12. Available online: https: / / www.nature.com/articles/s41396-021-00960-8 (accessed on 13 July 2021).

78. Rodríguez-Valera, F.; Juez, G.; Kushner, D.J. Halocins: Salt-dependent bacteriocins produced by extremely halophilic rods. Can. J. Microbiol. 1982, 28, 151-154. [CrossRef]

79. Torreblanca, M.; Meseguer, I.; Ventosa, A. Production of halocin is a practically universal feature of archaeal halophilic rods. Lett. Appl. Microbiol. 1994, 19, 201-205. [CrossRef]

80. Birbir, M.; Eryilmaz, S.; Ogan, A. Prevention of halophilic microbial damage on brine cured hides by extremely halophilic halocin producer strains. J. Soc. Leath. Tech. Chem. 2004, 88, 99-104.

81. Birbir, M.; Eryilmaz, S. Inhibiting lipolytic haloarchaeal damage on brine cured hides with halocin producer strains. J. Soc. Leath. Tech. Chem. 2007, 91, 69-72. 